\title{
Effects of Pretreatment of Platinum Surface on the Adsorption of Iodine from Aqueous Solutions
}

\author{
by \\ Shaw-chii Wu, , Si-jung YeH* and Mutsuaki ShinagawA** \\ *Institute of Nuclear Science, National Tsing Hua University, Taiwan, China \\ **Laboratory of Nuclear Engineering, Faculty of Engineering, Osaka, Japan
}

(Received Jan. 9, 1968)

\begin{abstract}
Three kinds of platinum surface, i.e. oxidized platinum surface, reduced platinum surface and partially reduced platinum surface were prepared to adsorb iodine from acidic aqueous potassium iodide solutions. It was found that the oxidized platinum surface adsorbed more iodine than both the reduced platinum surface and the partially reduced platinum surface under the same conditions studied.

When the adsorption temperature was raised increases in adsorption capacity and adsorption rate were observed for the oxidized platinum surface, but very little effect was observed for the reduced and the partially reduced platinum surface.

The effect of nitrogen on the adsorption of iodine onto platinum surface was also investigated.

\section{Introduction}

Controversial arguments have been postulated on the adsorption behavior of iodine onto platinum surface from aqueous solutions. Some workers reported that only a monolayer adsorption would be obtained when iodine was adsorbed on the reduced platinum surface ${ }^{122) 3)}$. Osteryoung et.al. postulated that iodine but not iodide is adsorbed on platinum surface ${ }^{4) 5}$. Nevertheless, in a recent study the same authors reviewed their results and concluded that both iodine and iodide are adsorbed on platinum surface but only the iodine displays electrochemical activity in the vicinity of the reversible iodideiodine potential ${ }^{6)}$. Schuldiner et. $\mathrm{al}^{7)}$ and others ${ }^{8)}$ have suggested that iodide is oxidized to iodine by sorbed oxygen in platinum and adsorbed on platinum surface. Although some additional work have been reported in the literature ${ }^{9) 10}$, it seems that much more work have to be done to understand the behavior of adsorption of iodine on platinum surface, which is suitable for carrierfree preparation of $1-131^{2}$.

The present work was carried out to study the effects of the pretreatment of platimun surface on the adsorption of iodine from dilute aqueous solution of iodide. The platinum surface was treated at various polarization potentials for different periods of time. The oxidized surface was also prepared by oxidizing agents for comparision. The effects of adsorption temperature on the capacity of adsorption and rate of adsorption were also studied. Finally, the influence of nitrogen atomosphere on the adsorption of iodine onto platinum surface was also investigated.
\end{abstract}

The fresent research was carried out while M. Shinagawa had been at the National Tsing Hua University as a guest professor from September, 1965 to January, 1966. 


\section{Experimental}

\section{Material}

Radiotracer: I-131 was used as tracer in this work, Carrier-free I-131 was obtained from the Radioisotope Laboratory of the National Tsing Hua University.

Potassium iodide solution: The C.P. grade potassium iodide was used to prepare the stock solution $\left(2.5 \times 10^{-6} \mathrm{M}\right)$, which was stored in a dark bottle and placed in a cool dark place.

Platinum: The platinum wire was made in spiral form and one of its ends was sealed into a glass tube. The diameter of the platinum wire was $1.1 \mathrm{~mm}$ and the length was $11.4 \mathrm{~cm}$, in the result its apparent surface area was $3.9 \mathrm{~cm}^{2}$.

All the other chemicals used in this experiment were of C.P. grade and used without further purification.

\section{Potentiostat and thermostat}

The modified Lingane's constant potential device was used throughout this work. The sensitivity with respect to change in electrode potential was about $1 \mathrm{mV}$. and the instantaneous deviation from the control point was not more than $\pm 10 \mathrm{mV}$. A saturated calomel electrode was used as a reference electrode.

The temperature of adsorption was controlled within $\pm 0.1^{\circ} \mathrm{C}$ using the Acme thermostat.

\section{Pretreatment of platinum surface}

$(A)$ Cleaning of platinum surface: In order to obtain unique platinum surface for adsorption experiment the platinum spiral was subjected to the following cleaning process before pretreatment:

(1) The adsorbed iodine was desorbed by cathodic polarization in $0.1 \%$ sodium sulfite solution at $-1.0 \mathrm{~V}$ vs S.C.E. for 30 minutes.

(2) The platinum spiral was then anodically polarized in $1 \mathrm{~N} \mathrm{H}_{2} \mathrm{SO}_{4}$ solution at 1.5 $\mathrm{V}$ vs S.C.E. for 1 minute.

(3) Finally, the platinum spiral was cathodically polarized in $1 \mathrm{~N}_{2} \mathrm{SO}_{4}$ solution at-0.7 V vs S.C.E. for 10 minutes. Step (2) was found to be very effective to remove trace of residual iodine on the platinum surface. This step is necessary, because the residual iodine is rather tightly adsorbed on the platinum surface and can not be removed even after treated by step (1) for several hours. Step (3) was used to remove any platinum oxide previously formed in step (2). The platinum surface cleaned by this process, though it might cause adsorption of hydrogen to some extent, was then used for further pretreatment as described below.

(B) Pretreatment of platinum surface by electrochemical method: The cleaned platinum surface was treated by anodic or cathodic polarization at room temperature, A $3.0 \mathrm{~cm}^{2}$ platinum foil was used as an auxilliary electrode during each polarization.

(1) "Oxidized" platinum surface: The cleaned platinum surface was anodized in $1 \mathrm{~N} \mathrm{H}_{2} \mathrm{SO}_{4}$ solution at different potentials for different periods of time.

(2) "Reduced" platinum surface: The cleaned platinum surface was cathodized in $1 \mathrm{~N} \mathrm{H}_{2} \mathrm{SO}_{4}$ solution at different potentials for different periods of time.

(3) "Partially reduced" platinum surface: The cleaned platinum surface was anodized at $0.5 \sim 2.0 \mathrm{~V} v s$, S.C.E. for 10 minutes and subsquently cathodized at $-0.3 \mathrm{~V}$ 
vs, S.C.E. for 2 minutes. The potential was chosen so that the electrode adsorb hydrogen at least extent according to Kolthoff and Tanaka ${ }^{11)}$.

(C) Pretreatment by chemical method.: The oxidized platinum surface can also be prepared by chemical method. The cleaned platinum surface was dipped into the acidic solutions of strong oxidizing agents for predetermined time to make oxidized platinum surface as shown below ${ }^{11)}$.

Oxidizing agents

$0.1 \mathrm{~N} \mathrm{~K}_{2} \mathrm{Cr}_{2} \mathrm{O}_{7}$ in $1 \mathrm{~N} \mathrm{H}_{2} \mathrm{SO}_{4}$

$0.1 \% \mathrm{KMnO}_{4}$ in $1 \mathrm{~N}_{2} \mathrm{SO}_{4}$

$0.1 M \mathrm{Ce}\left(\mathrm{SO}_{4}\right)_{2}$ in $0.5 \mathrm{~N} \mathrm{H}_{2} \mathrm{SO}_{4}$

$0.1 M \mathrm{Ce}\left(\mathrm{SO}_{4}\right)_{2}$ in $0.5 \mathrm{~N} \mathrm{H}_{2} \mathrm{SO}_{4}$

\section{Time of dipping}

$15 \mathrm{~min}$.

5 min.

$15 \mathrm{~min}$.

18 hours

\section{General procedure for the adsorption measurements}

(A) Adsorption of iodine in the aerated system. A $40 \mathrm{ml}$ tube was used as the adsorption vessel which was placed in a water bath regulated at desired temperature by Acme thermostat. Twenty $\mathrm{m} l$. of $2.5 \times 10^{-6} \mathrm{M}$ potassium iodide was placed in the adsorption vessel and a small amount of iodide form carrier-free I-131 was added as a tracer. The solution was then made $1 N$ with respect to $\mathrm{H}_{2} \mathrm{SO}_{4}$. The pretreated platinum surface was dipped into the solution to adsorb the iodine. At predetermined time interval, the platinum was taken out, washed very thoroughly with distilled water*), and put into PVG tube for radioactivity measurement with NRD well type scintillation counter using $\mathrm{NaI}(\mathrm{Tl})$ crystal. The amount of iodine adsorbed on the platinum surface was estimated by the following formula.

$$
I_{a d}=\frac{A_{a d}}{A_{t}} \times \frac{C}{S}
$$

where

$I_{a d}$ : Amount of iodine asdorbed on the platinum surface per unit surface area.

$A_{a d}:$ Radioactivity of iodine adsorbed on the platinum surface.

$A_{t}$ : Total radioactivity of $\mathrm{I}-131$ initially added to the potassium iodide solution.

$S$ :Apparent surface area of platinum surface.

$G$ : Initial concentration of potassium iodide in the solution.

(B) Adsorption of iodine under nitrogen atomosphere: A $30 \mathrm{~m} l$ glass vessel with a gas inlet and outlet was used as the adsorption vessel. Twenty $\mathrm{m} l$ of $2.5 \times 10^{-6} \mathrm{M}$ potassium iodide solution was placed in the vessel and a small amount of carrier-free I-131 was added as a tracer. After the solution was made $1 N$ with respect to $\mathrm{H}_{2} \mathrm{SO}_{4}$, the oxygen free nitrogen gas was slowly bubbled through the solution for half an hour during the platinum spiral had been dipped into the solution for adsorption. Even each time when the platinum spiral was taken out for radioactivity measurement, the nitrogen gas was allowed to bubble through the solution to prevent redissolving of oxygen in the solution. The rest of the procedure was entirely the same as described before.

\section{Results and Discussion}

1. Adsorption of iodine onto oxidized platinum surface.

Effects of pretreatment anodic potential on the capacity and the rate of adsorption.

\footnotetext{
* It has been corformed that careful jet out of a washing bottle containing distilled water was enough to drive away radioactive iodide even from the site of glass seal of platinum wire.
} 
Platinum surface treated with different anodic potentials $(0.5 \sim 2 \mathrm{~V} v$ s. S.C.E. $)$ was used to adsorb iodine from $2.5 \times 10^{-6} \mathrm{M}$ potassium iodide solution prepared in $1 \mathrm{~N} \mathrm{H}_{2} \mathrm{SO}_{4}$ at $25^{\circ} \mathrm{C}$. The results are summarized in Fig. 1. It was observed that the higher the anodization potential used for pretreatment of the platinum surface, the higher the capacity of adsorption was obtained. This trend is rather straight forward, because it is generally believed that platinum oxide formed on the platinum surface by anodic polarization increases with the increase in anodic potential ${ }^{12-15}$.

Concerning the rate of adsorption, it is noteworthy to point out that the higher the

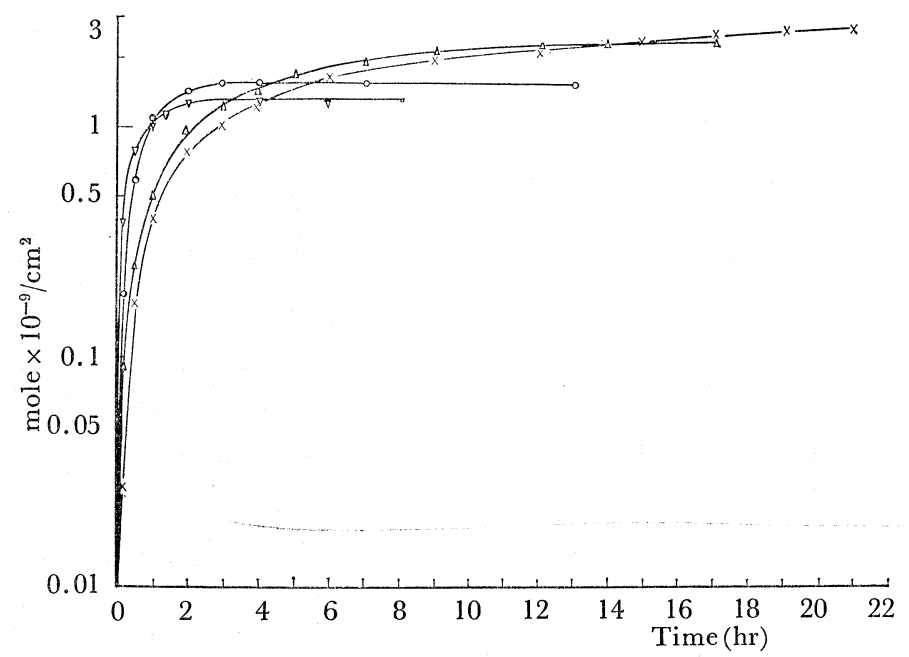

Fig. 1. Adsorption of iodine on oxidized $P t$ surface at $25^{\circ} \mathrm{C}$. Anodization for $10 \mathrm{~min} ; \quad x: 2.00 \mathrm{~V}, \triangle: 1.50 \mathrm{~V}, \bigcirc: 1.00 \mathrm{~V}, \nabla: 0.50 \mathrm{~V}$.

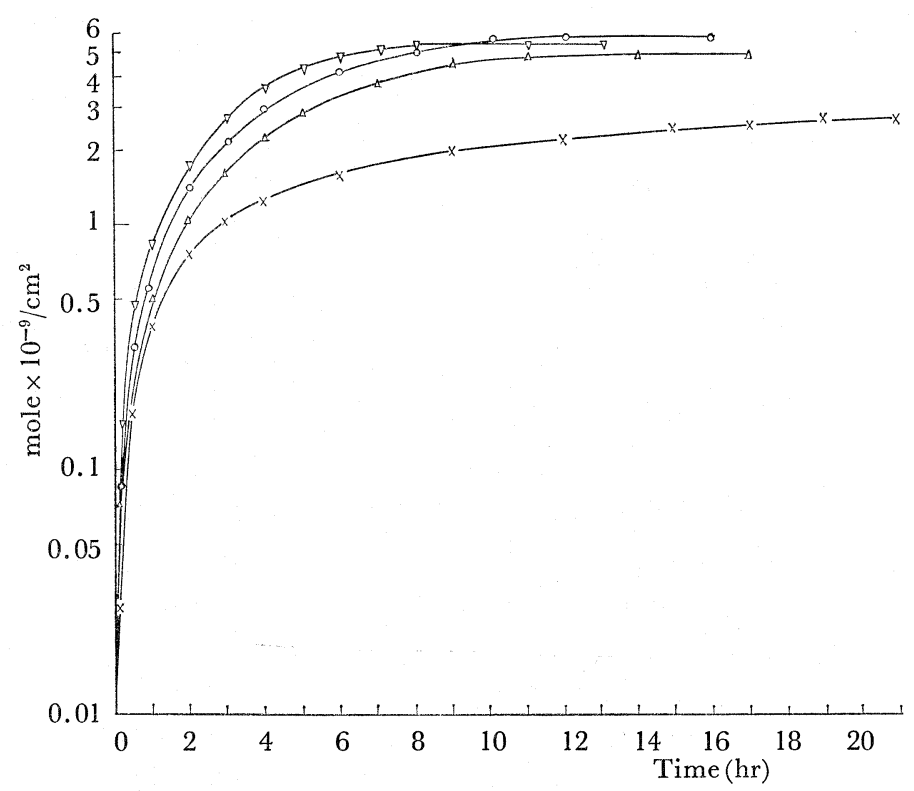

Fig. 2. Adsorption of iodine at different temperatures on oxidized $P t$ surface pretreated with anodic potential at $2.00 \mathrm{~V}$ vs. S.C.E. for $10 \mathrm{~min}$. $\nabla: 50^{\circ} \mathrm{C}, \bigcirc: 45^{\circ} \mathrm{C}, \triangle: 40^{\circ} \mathrm{C}, \times: 25^{\circ} \mathrm{C}$. 
pretreatment anodic potential for is applied to the platinum electrode, the slower is the rate of adsorption. This is probably due to the fact that the platinum oxide forms rather tight structure on treatment with high anodic potential or strong oxidizing agent ${ }^{15) 16}$ ) and that it is more difficult to interact with iodide.

Effect of temperature of adsorption on the capacity and the rate of adsorption.

Fig. 2 shows the effects of temperature of adsorption on the capacity and the rate of adsorption for the platinum surface anodized at $2.0 \mathrm{~V} v s$. S.C.E. for 10 minutes. It is clear that both the capacity and the rate of adsorption increase as the temperature of adsorption is raised from $25^{\circ} \mathrm{C}$ to $50^{\circ} \mathrm{C}$. This may be due to the fact that the interaction between the iodide and platinum oxide are enhanced at higher temperatures. In an attempt to obtain more detailed informations the platinum surface pretreated with different anodic potentials $(0.5 \mathrm{~V}-2.0 \mathrm{~V}$ vs. S.C.E. $)$ was used to adsorb iodine at $45^{\circ} \mathrm{C}$, and the results are summarized in Fig. 3. By comparing Fig. 1 and Fig. 3, it is very interesting to note that both the rate and capacity of adsorption are sharply increased by raising the temperature of adsorption.

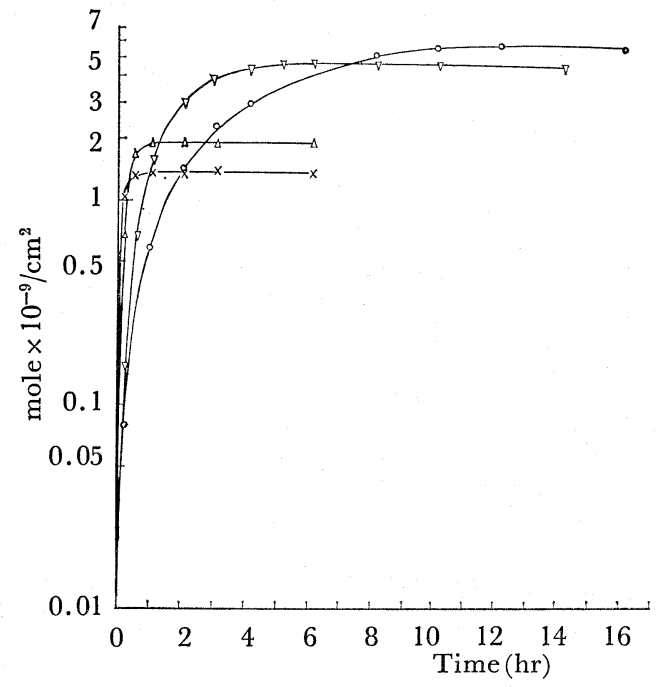

Fig. 3. Adsorption of iodine on oxidized $P t$ surface at $45^{\circ} \mathrm{C}$. Anodization for $10 \mathrm{~min}$. $\bigcirc: 2.00 \mathrm{~V}, \nabla: 1.50 \mathrm{~V}, \triangle: 1.00 \mathrm{~V}, \times: 0.50 \mathrm{~V}$.

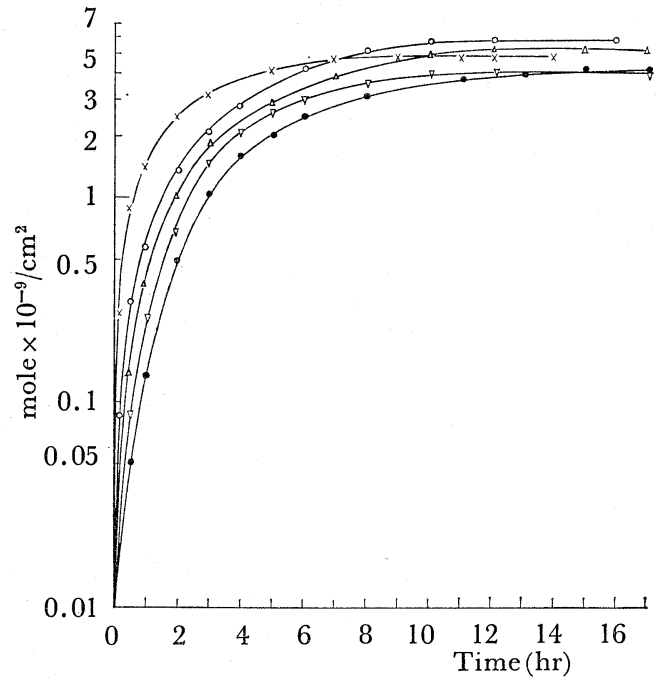

Fig. 4. Adsorption of iodine on oxidized $P t$ surface at $45^{\circ} \mathrm{C}$. Anodized at $2.00 \mathrm{~V}$ vs S.C.E. $\times: 5 \mathrm{~min} ., \bigcirc: 10 \mathrm{~min} ., \triangle: 20 \mathrm{~min}$, $\nabla: 60 \mathrm{~min} ., \mathrm{s}: 300 \mathrm{~min}$.

Effects of pretreatment time on the capacity of adsorption.

The platinum surface was anodized at $2.0 \mathrm{~V} v$ s. S.C.E. for different period of time and used to study the effects of pretreatment time on the adsorption of iodine at $45^{\circ} \mathrm{C}$. As is shown in Fig. 4, it was observed that highest adsorption capacity was obtained for the platinum surface pretreated for ten minutes. Longer period of pretreatment gives lower adsorption capacity. Fig. 5 shows the effects of temperature on the adsorption of iodine onto platinum surface pretreated for one hour at the anodic potential $2.0 \mathrm{~V} v \mathrm{~s}$. S.C.E.. The difference in adsorption capacity at the temperature range $35^{\circ} \mathrm{C} \sim 60^{\circ} \mathrm{C}$ was not significant. Thus the longer period of anodic polarization at high potential $(2.0 \mathrm{~V} v s$. S.C.E. $)$ gives rather tight oxide structure as well as the constant amount of platinum oxide ${ }^{14)}$. 


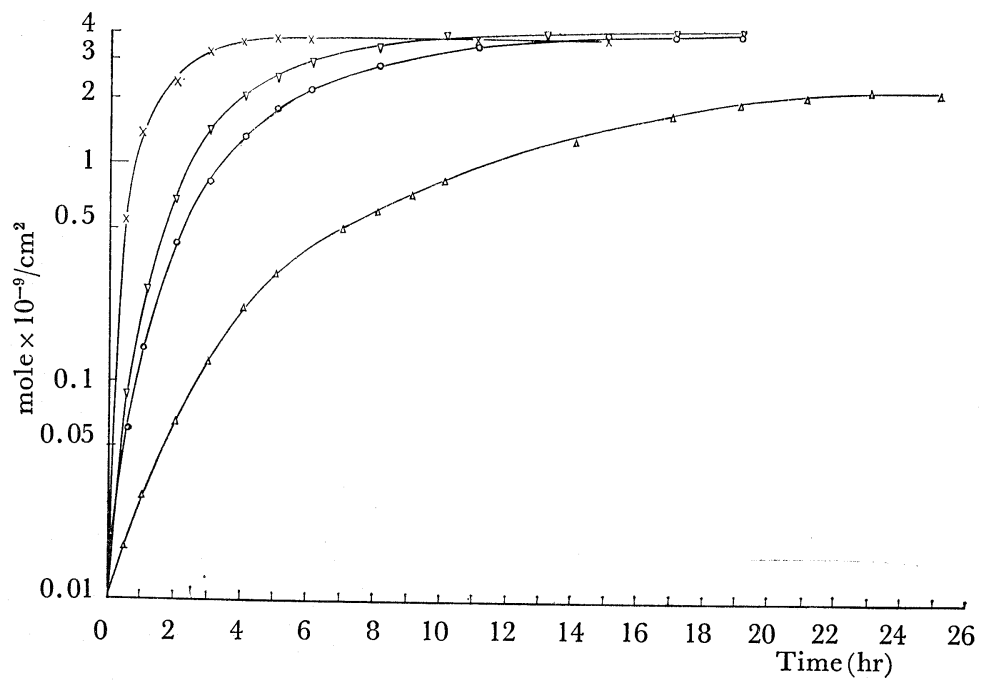

Fig. 5. Adsorption of iodine at different temperatures on oxidized $P t$ surface pretreated at $2.00 \mathrm{~V}$ vs S.C.E. for $60 \mathrm{~min} . \times: 60^{\circ} \mathrm{C}, \nabla: 45^{\circ} \mathrm{C}, \bigcirc: 35^{\circ} \mathrm{C}$, $\triangle: 25^{\circ} \mathrm{C}$.

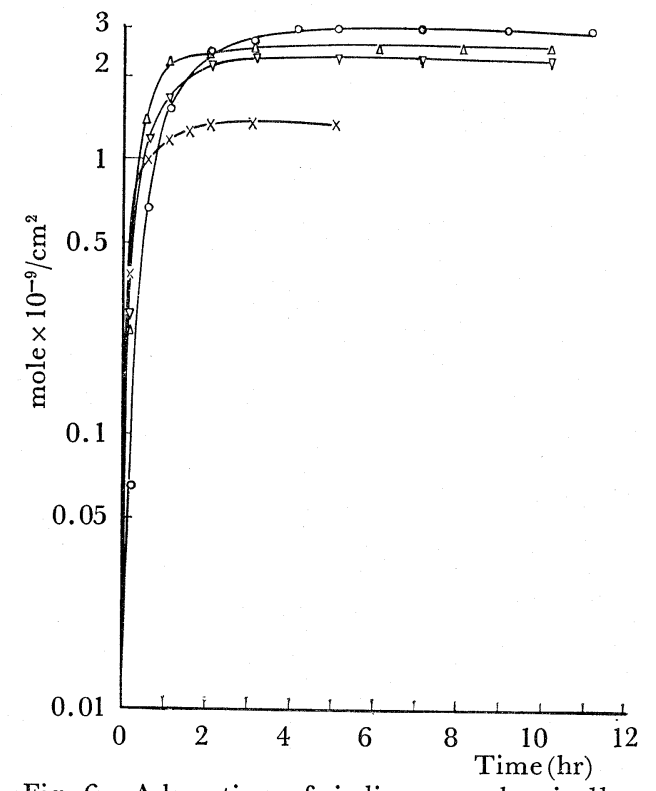

Fig. 6. Adsorption of iodine on chemically oxidized $P t$ surface at $45^{\circ} \mathrm{C}$.

$\bigcirc: 0.1 M \mathrm{Ce}\left(\mathrm{SO}_{4}\right)_{2}$ in $0.5 \mathrm{~N} \mathrm{H}_{2} \mathrm{SO}_{4}$ for 18 hrs.

$\triangle: 0.1 M \mathrm{Ce}\left(\mathrm{SO}_{4}\right)_{2}$ in $0.5 \mathrm{~N} \mathrm{H}_{2} \mathrm{SO}_{4}$ for 15 $\min$.

$\nabla: 0.1 \% \mathrm{KMnO}_{4}$ in $1 \mathrm{~N} \mathrm{H}_{2} \mathrm{SO}_{4}$ for $5 \mathrm{~min}$. $\times: 0.1 M \mathrm{~K}_{2} \mathrm{Cr}_{2} \mathrm{O}_{7}$ in $1 \mathrm{~N} \mathrm{H}_{2} \mathrm{SO}_{4}$ for $15 \mathrm{~min}$.

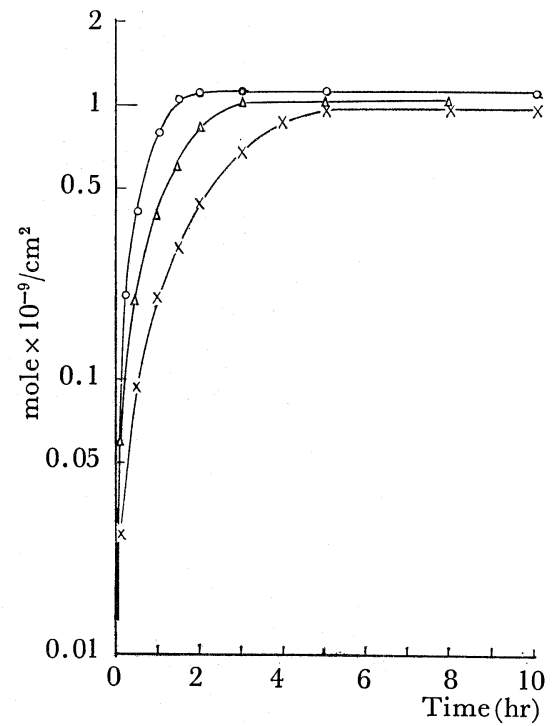

Fig. 7. Adsorption of iodine on reduced $P t$ surface.

$O$ : clean $P t$ surface at $45^{\circ} \mathrm{C}$.

$\triangle$ : clean $P t$ surface at $25^{\circ} \mathrm{C}$.

$\times$ : cathodized at $-0.70 \mathrm{~V}$ vs S.G.E. for $180 \mathrm{~min}$. , at $25^{\circ} \mathrm{C}$.

Effects of pretreatment with different chemical oxidizing agents on the capacity of adsorption. Platinum oxide can be formed on the platinum surface by chemical method ${ }^{11}$ ) ${ }^{16) 17)}$. Kolthoff and Tanaka ${ }^{11}$ have prepared platinum oxide with various oxidizing agents and measured the amount of platinum oxide by polarography. In this work 
several strong oxidizing agents was selected to treat the platinum surface for the adsorption of iodine. The results are summarized in Fig. 6. It is found that the platinum surface treated with ceric sulfate for 18 hours in acidic solution gives the highest adsorption capacity. However, the platinum surface treated with oxidizing agent in general gives lower adsorption capacity than that treated by high anodic polarization.

2. Adsorption of iodine on reduced platinum surface

In order to compare the capacity of adsorption the reduced platinum surface was prepared by cathodic polarization under vairous conditions and used for adsorption of iodine. The results are summarized in Fig. 7. It can be seen in the Fig. 7 that the amount of iodine adsorbed by the reduced platinum surface is lower compared to the cleaned platinum surface.

The increase in the time of cathodic polarization shows no marked effect on the capacity of adsorption. Raising temperature of adsorption also has little effect on the capacity of adsorption, which trends are very much different from those of the oxidized platinum surface. The trend of negative effect for iodine adsorption can be seen by cathodization, which makes hydrogen to be adsorped on the electrode surface.

\section{Adsorption of iodine on the partially reduced platinum surface.}

Fig. 8 shows the adsorption of iodine onto the partially reduced platinum surface pretreated by anodization at the potential range $0.5 \sim 2.0 \mathrm{~V}$ vs. S.C.E. for 10 minutes and subsquently by cathodization at- $0.3 \mathrm{~V}$ vs. S.C.E. for 2 minutes. It is apparent that the capacity of adsorption of the partially reduced platinum surface is slightly greater than that of reduced platinum surface. (cf. Fig. 7 and 8). Nevertheless, its rate of adsorption is much faster and reaches adsorption saturation almost within one hour. There is also no temperature effect on the capacity of adsorption.

4. Adsorption of iodine under the nitrogen atomosphere.

Both the reduced platinum surface and the oxidized platinum surface were used to adsorb the iodine from the $2.5 \times 10^{-6} \mathrm{M}$ potassium iodide solution prepared in $1 \mathrm{~N} \mathrm{H}_{2} \mathrm{SO}_{4}$ at $25^{\circ} \mathrm{C}$. The oxygen dissolved in the solution was expelled by bubbling through oxygen free nitrogen gas and the adsorption of iodine onto platinum surface was carried out under the nitrogen atomosphere throughout the whole experiment. As is shown in Fig. 9, both the capacity and the rate of adsorption for the reduced surface are decreased rather sharply compared to those of oxidized platinum surface. The capacity of adsorption of oxidized platinum surface obtained under the nitrogen atomosphere showed little difference from that of in the aerated system. (c.f. Fig. 1) It is interesting to point out that the adsorption of iodine on the platinum surface may be mainly dependent on the platinum oxide in sulfuric acid which functions as an oxidizing agent in the course of adsorption.

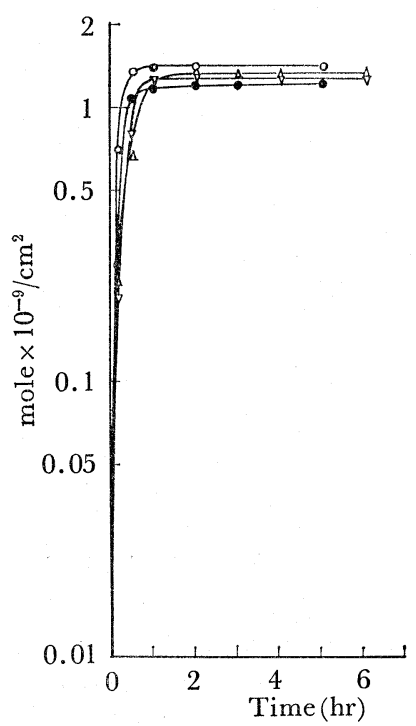

Fig. 8. Adsorption of iodine on partially reduced $P t$ surface. $\mathrm{O}$ : anodized at $2.00 \mathrm{~V}$, adsorption at $45^{\circ} \mathrm{C}$.

$\triangle$ : anodized at $2.00 \mathrm{~V}$, adsorption at $25^{\circ} \mathrm{C}$.

$\nabla:$ anodized at $1.50 \mathrm{~V}$, adsorption at $25^{\circ} \mathrm{C}$.

- anodized at $0.50 \mathrm{~V}$, adsorption at $25^{\circ} \mathrm{C}$. 


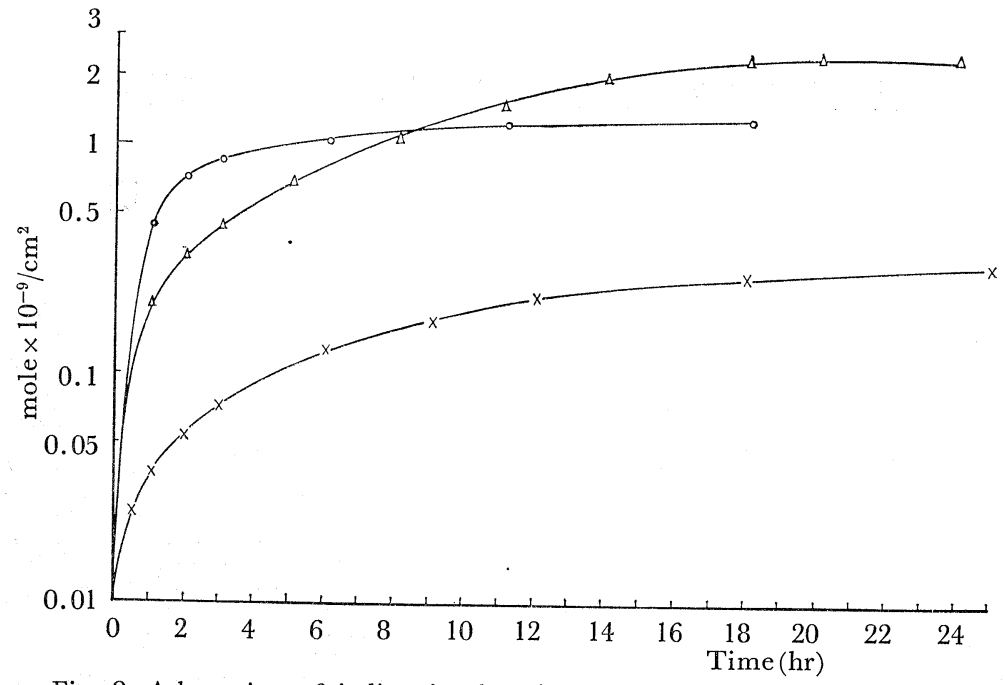

Fig. 9. Adsorption of iodine in the nitrogen gas atomosphere at $25^{\circ} \mathrm{C}$.

$\times$ : reduced $P t$ surface cathodized at $-0.70 \mathrm{~V}$ os S.G.E. for $180 \mathrm{~min}$.

$\bigcirc$ : oxidized $P t$ surface anodized at $1.00 \mathrm{~V}$ os S.C.E. for $10 \mathrm{~min}$.

$\triangle$ : oxidized $P t$ surface anodized at $2.00 \mathrm{~V}$ ws S.C.E. for $10 \mathrm{~min}$.

\section{Acknowledgement}

This work is partially supported by the research grant of National Council on Science Development , China to whom thanks are due.

\section{References}

1) G. Toth, J. Inorg. Nucl. Chem., 19, 1860 (1961).

2) G.C. Lin, G.T. Chang, and S.J. Yeh, J. Atom. Energy Soc., Japan, 5, No. 3, 187 (1963).

3) G. Toth, Radiokimiya, 5 (4), 411 (1963).

4) R.A. Osteryoung, G. Lauer and F.G. Anson, Anal. Chem., 34, 183 (1962).

5) R.A. Osteryoung, G. Lauer and F.G. Anson, J. Electrochem. Soc., 110, 926 (1963).

6) R.A. Osteryoung and F.C. Anson, Anal. Chem., 36, 975 (1964).

7) S. Schuldiner and T.B. Warner, Anal. Chem. 36, 2510 (1964).

8) V.A. Zakharov and O.A. Songina, Chem. Abstr., 57, 8348d (1962).

9) S. Schuldiner and C.H. Presbrey, Jr., J. Electrochem. Soc., 111, 457 (1964).

10) J.D. Newson and A.G. Riddiford, J. Electrochem. Soc., 108, 699 (1961).

11) I.M. Kolthoff and N. Tanaka, Anal. Chem., 26, 632 (1954).

12) S. Schuldiner and T.B. Warner, J. Electrochem. Soc., 112, 212, (1965).

13) M.W. Breiter, J. Electrochem. Soc., 109, 425 (1962).

14) J.S. Mayell and S.H. Langer, J. Electrochem. Soc., 111, 438 (1964).

15) S.W. Feldberg, G.G. Enke and G.B. Bricker, J. Electrochem. Soc., 110, 826 (1963).

16) F.C. Anson and J.J. Lingane, J. Am. Chem. Soc., 79, 4901 (1957).

17) B.B. Baker and W.H. MacNevin, J. Am. Chem. Soc., 75, 1476 (1953). 
水溶液からヨウ素を吸着する白金表面の前処理効果

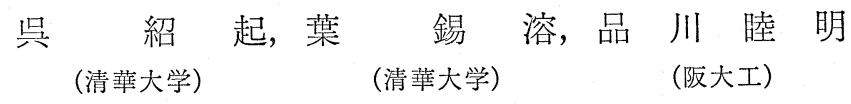

太い白金線端をガラス管にシールし， $3.9 \mathrm{~cm}^{2}$ の面 積上に，ヨウ化カリウムの硫酸酸性溶液からヨウ素が 吸着する様子をしらべた。白金表面は，まづ一定の陰 性, 陽性の分極化によつて清浄にしたのち，なお所定 の酸化，還元及び部分的還元処理を施した。酸化に は，薬品による酸化処理の場合も比較の対象とした。 吸着後の白金表面のヨウ素の分析は， ${ }^{131} \mathrm{I}$ のガンマ線 を用いシンチレーション計数によつて行つた。

一定時間，溶液中に浸漬してのち白金表面を水洗し たとして，一般にヨウ素の吸着は酸化前処理白金にお いてては，還元処理のものよりも多いととがわかつ
た。そして, 吸着時の液温を上げると, 吸着容量及び 吸着速度は共に上るが，その程度も，酸化処理白金の 場合に著しく，還元処理のものや部分的還元好理のも のでは，ほとんど効果が見受けられなかつた。

なお吸着試験溶液に窒素を通じ, 溶液酸素を追出し たものについての試験も行つた。還元処理白金では脱 気しない場合に比して著しく吸着量が減少し, 酸化処 理のものでは，さほどもなかつた。このてとから，溶 液酸素は吸着途上でもその酸化力によつて吸着を助け るものと考えられる。 